\title{
The Role of Priests and Levites in the Composition of Ezra-Nehemiah: Some Points for Consideration
}

\section{Introduction}

The text of Ezra-Nehemiah focuses on events related to the settlement and establishment of Judah, more specifically, Jerusalem, from the period directly after Cyrus' conquest of Babylon to the periods of Ezra and Nehemiah. ${ }^{1}$ The priests and Levites (along with other groups connected to the temple administration) are depicted as central to the settlement and establishment of Judah and Jerusalem within the different narrative vignettes. Interspersed throughout the narrative vignettes are lists that mention the priests, Levites, and temple personnel, as well as non-cultic personnel who made up the Jerusalem and broader Judahite community. ${ }^{2}$ Since the priests and Levites are central figures in both the narratives and lists, certain scholars have examined the role these two groups may

1 Scholars continue to debate the exact dates that Ezra and Nehemiah came to Jerusalem. Scholars who support a return for Ezra and Nehemiah during the kingship of Artaxerxes I (ca. 458 and 445 BCE) include: H. G. M. Williamson, Word Biblical Commentary. 16: Ezra, Nehemiah, 5 (Waco, Texas: Word Books, 1985); Jacob M. Myers, Ezra, Nehemiah, AB 14 (New York: Doubleday, 1987); Joseph Blenkinsopp, Ezra-Nehemiah: A Commentary, Old Testament Library (London: SCM Press, 1989); Joseph Blenkinsopp, Judaism, the First Phase: The Place of Ezra and Nehemiah in the Origins of Judaism (Grand Rapids: Eerdmans, 2009); Kyung-Jin Min, The Levitical Authorship of Ezra-Nehemiah, JSOTSup 409 (London: T\&T Clark, 2004); Frank Charles Fensham, The Books of Ezra and Nehemiah, NICOT (Grand Rapids: Eerdmans, 2007). Scholars who support a return for Ezra during the kingship of Artaxerxes the II (398 BCE) include Joachim Schaper, Priester und Leviten im achämenidischen Juda: Studien zur Kult- und Sozialgeschichte Israels in persischer Zeit, FAT 31 (Tübingen: Mohr Siebeck, 2000); Diana Vikander Edelman, The Origins of the "Second" Temple: Persian Imperial Policy and the Rebuilding of Jerusalem, BibleWorld (London: Equinox, 2005); Lisbeth S. Fried, Ezra: A Commentary (Sheffield: Sheffield Phoenix Press Ltd, 2015); Bob Becking, Ezra-Nehemiah, Historical Commentary on the Old Testament (Leuven; Bristol, CT: Peeters, 2018). See Becking, Ezra-Nehemiah, 98-100 for a more thorough list of scholars who support Ezra's return during Artaxerxes I or II.

2 These lists include Ezra 2//Nehemiah 7, Ezra 7, 8, 10:18-43, Neh 3:1-32, 10:2-28, 11:4-24, and 12.

Deirdre Fulton, Baylor University 
have played in the composition of Ezra-Nehemiah. ${ }^{3}$ Additionally, while earlier scholarship focused on compositional unity or disunity with Chronicles, more recent scholarship has focused on more specific questions about the unity or disunity of Ezra-Nehemiah itself. ${ }^{4}$ This focus on priestly and/or Levitical authorship of Ezra-Nehemiah is hardly surprising, given that one of the most significant moments is found in Nehemiah 8 when Ezra presents the Torah of Moses to the community.

While the priests and Levites are prominent in Ezra-Nehemiah, the close geographical proximity of these groups leads other scholars to argue for a scribal community that is in close contact with both priestly and Levitical guilds. ${ }^{5}$ Through these inter-group debates, the text of Ezra-Nehemiah underwent textual changes that preserve decidedly pro-priestly and pro-Levitical (as well as antipriestly and anti-Levitical) editing to the text. In what follows, I explore certain passages to investigate priestly and Levitical portrayals within the Ezra-Nehemiah corpus. Some of the key passages referring to priests and Levites include their first and last appearances in Ezra-Nehemiah (Ezra 1 and Nehemiah 13), the settlement of Judah in the time of Jeshua and Zerubbabel (Ezra 3), Ezra's first appearance and return to Judah (Ezra 7-8), the reading of the Torah by Ezra (Neh 8), and the dedication ceremonies in Jerusalem (Nehemiah 9-10 and 12).

3 Cf. Williamson, Word Biblical Commentary. 16; Min, Levitical Authorship; Juha Pakkala, Ezra the Scribe: The Development of Ezra 7-10 and Nehemiah 8, BZAW 347 (Berlin: De Gruyter, 2004). Pakkala argues for several different editorial changes to Ezra over two centuries (at least), and one of these editorial changes is Levitical in nature, but preserving both priestly and Levitical interests. 4 For a discussion of Chronicles-Ezra-Nehemiah, see Sara Japhet, "The Supposed Common Authorship of Chronicles and Ezra-Nehemia Investigated Anew,” VT 18 (1968): 330-71; Thomas Willi, Die Chronik als Auslegung, FRLANT 106 (Göttingen: Vandenhoeck \& Ruprecht, 1972); H. G. M Williamson, Israel in the Book of Chronicles (Cambridge: Cambridge University Press, 1977); Tamara Cohn Eskenazi, In an Age of Prose: A Literary Approach to Ezra-Nehemiah, Society of Biblical Literature Monograph Series 36 (Atlanta: Scholars Press, 1988); Blenkinsopp, Ezra-Nehemiah. For a discussion of the unity or disunity in Ezra-Nehemiah, see James C. VanderKam, "Ezra-Nehemiah or Ezra and Nehemiah?" in Priests, Prophets, and Scribes: Essays on the Formation and Heritage of Second Temple Judaism in Honour of Joseph Blenkinsopp, ed. Eugene Ulrich et al., Journal for the Study of Judaism Supplement Series 149 (Sheffield: Sheffield Academic Press, 1992); Mark J. Boda and Paul L. Redditt, eds., Unity and Disunity in Ezra-Nehemiah: Redaction, Rhetoric and Reader (Sheffield: Sheffield Phoenix, 2008); Christopher Jones, "Embedded Written Documents as Colonial Mimicry in Ezra-Nehemiah,” Biblical Interpretation 26 (2018):158-81; Nissim Amzallag, "The Authorship of Ezra and Nehemiah in Light of Differences in Their Ideological Background,” JBL 137/2 (2018):271-97; Becking, Ezra-Nehemiah.

5 Cf. Williamson, Word Biblical Commentary. 16; Jones, "Embedded Written Documents," 162. Jones does not argue for priestly or Levitical authorship, but rather "an educated scribal literati." See below for discussion. 
I do not seek to revisit the different compositional models for Ezra-Nehemiah in light of priestly or Levitical authorship, an increasingly growing area of scholarship over the past 20 years, but rather to explore how these texts present the temple elite in light of Torah. ${ }^{6}$ The differences in the presentation of the priests and Levites in Ezra and Nehemiah highlight certain issues concerning common authorship of these texts, as well as arguments for priestly or Levitical authorship. As I argue, the behaviors of the priests are functional and less prescriptive in nature. That is, the priests and Levites oftentimes are functionaries on behalf of the people within their cultic roles in Ezra-Nehemiah. ${ }^{7}$ Yet these narratives are not meant to enforce established, or accepted, behaviors since the cultic functions are not, at times, exclusively the role of the priests and Levites. Rather, they are the role of the entire community, which is also deemed holy. ${ }^{8}$

\section{Priests and Levites in Ezra-Nehemiah}

Priests and Levites are central actors throughout the book of Ezra-Nehemiah. Upon first glance, the priests and Levites appear to be represented equally within the cultic and sacral life of the Jerusalem community since both are generally found together. ${ }^{9}$ The first reference to the priests in Ezra is accompanied by the Levites (Ezra 1:5). Ezra-Nehemiah ends with a reference to both the priests and Levites (Neh 13:30). The common appearance of both groups is evident throughout Ezra-Nehemiah, revealing their centrality within this text and their impor-

6 To be clear, these different compositional models are helpful for understanding textual formation and also help draw attention to textual tensions. My observations in this essay are not negating these diachronic models, but are simply examining the final product of Ezra-Nehemiah. I date the latest editorial layers to the late-Hellenistic Period.

7 Cf. Menahem Haran, Temples and Temple-Service in Ancient Israel: An Inquiry into the Character of Cult Phenomena and the Historical Setting of the Priestly School (Oxford: Clarendon, 1977). On p. 94 Haran maintains that during the time of Ezekiel, there was no Levitical class but was created by Ezekiel through "down-grading certain" non-Zadokite priests. He also notes that aside from P and "Ezekiel's code," there is no clear categorical division of rank between the priests and Levites except in Ezra, Nehemiah, and Chronicles.

8 Eskenazi, In an Age of Prose; Hannah K. Harrington, "Holiness and Purity in Ezra-Nehemiah," in Unity and Disunity in Ezra-Nehemiah: Redaction, Rhetoric, and Reader, eds. Mark J. Boda and Paul L. Redditt, Hebrew Bible Monographs 17 (Sheffield: Sheffield Phoenix Press, 2008), 98-116. 9 Min, citing Anderson and Forbes, notes that the term כהן appears 78 times in Ezra-Nehemiah and לו' לו' Sevpears 65 times. Min, Leval Authorship, 44-47; Francis I. Andersen and A. Dean Forbes, The Vocabulary of the Old Testament (Roma: Pontificio Istituto biblico, 1989). 
tance within the Jerusalem cultic community. In places, then, they seem to function simply as a means by which to denote cultic personnel generally.

Upon closer inspection and in different settings, however, priests and Levites have different functions in Ezra and Nehemiah, and on a smaller scale, the texts of Ezra and Nehemiah do not have unified presentations throughout each book. I offer several examples to highlight certain intertextual tensions regarding the role that the priests and Levites play in the Judahite community and how these moments may enlighten us to the goals of the editors in Ezra-Nehemiah. I begin with the framing narratives of Ezra 1 and Nehemiah 13 since they offer examples of how the portrayal of the priests and Levites differ dramatically.

\subsection{Ezra 1 and Nehemiah 13: The Introduction and Conclusion of the Priests and Levites}

In the first chapter of Ezra (1:5), the priests and Levites are part of the heads of the families (ראשי האבות) who return to rebuild the house of God in Jerusalem. King Cyrus is credited with giving vessels, originally from the House of the LORD that Nebuchadnezzar had taken away from Jerusalem, and entrusting them to Sheshbazzar, the "prince of Judah" (הנשיא ליהודה) who brings them from Babylon to Jerusalem. Within this narrative, the priests and Levites are part of the prominent returnees - mentioned after the Judahites and Benjaminites - but are given no formal position to aid in the return of the freewill offerings of animals or vessels, including the cultic paraphernalia said to be from the first temple that Nebuchadnezzar destroyed.

Similarly, in the first-person narrative of Nehemiah 13, among his final reforms, Nehemiah (v. 30) claims "I purified them of everything foreign, and I established the duties of the priests and Levites, specific duties for each person" (וטהרתים מכל־נכר ואעמידה משמרות לכהנים וללוים איש במלאכתו). Both priests and Levites are mentioned, and the need for purification is because of their impurity in connection to their marriage to foreign women. It is noteworthy, however, that the only people named are the sons of Joiada, son of Eliashib the high priest, because his son-in-law was Sanballat the Horonite. Thus, certain priests are indicted and named, but not the Levites. In the compositional schema of this passage, certain scholars argue for the dependence of Nehemiah 13:23-31 on Ezra 9-10 (or vice versa), and both texts are dependent on Deuteronomy 7 and 23. ${ }^{10}$ Juha Pakkala

10 Pakkala, Ezra the Scribe, 223-24; Jacob L. Wright, Rebuilding Identity: The Nehemiah-Memoir and Its Earliest Readers, BZAW 348 (Berlin: de Gruyter, 2004). See Pakkala for a discussion of the textual priority of Ezra 9-10 over against Neh 13:23-31, and see Wright for the opposite view. 
also sees Nehemiah 13:23-31, which he argues is the "youngest expansion to the book" as well as the older vv. 1-14, as decidedly pro-Levitical albeit from a different compositional stratum. ${ }^{11}$ Certainly, Nehemiah 13 is more favorable toward the Levites than the priests.

In both Ezra 1 and Nehemiah 13, the activities one would expect the priests and Levites to perform in light of Torah regulations, namely the transport of sacred vessels and freewill offerings from Babylon to Judah and the purification of the community, are performed by non-cultic officiants: Sheshbazzar the "prince" of Judah and Nehemiah the "governor." 12 To add to this list of activities one would expect cultic officiants to perform, the larger narrative of Nehemiah 13 consistently takes the agency of reform away from the priests - and to a lesser degree Levites - and places it in the hands of Nehemiah. These reforms include the already-mentioned separation from foreign wives, but also include the threat of the Moabites and Ammonites in the community (vv. 1-3), the removal of Tobiah from rooms in the Temple (v. 8), the purification of these rooms and return of temple vessels (v. 9), the gathering of the Levites back to the temple from their villages (v. 11), the appointing of priestly, scribal, and Levitical treasurers (v. 13) and finally, the enforcing of Sabbath regulations (vv. 15-20). Crediting Nehemiah with these reforms may be viewed as a critique of the priests since it would have been their prerogative and not that of the lesser Levites. Additionally, if these texts are prescriptive in nature, they provide further evidence that this is a critique of the priests since they are not performing their cultic roles. Lisbeth Fried argues that Nehemiah's actions may be to curb high priestly powers. ${ }^{13}$ Sean Burt counters that the religious reforms may have served the purpose of eliminating "sources of competition for Persian power and tribute." ${ }^{14}$ Certainly, giving credit

11 Pakkala, Ezra the Scribe, 224. Pakkala's model addresses the fact that Ezra 1 does not mention Ezra the priest and scribe at all, but rather mentions Sheshbazzar.

12 For a discussion of the titles "governor" in Ezra-Nehemiah, see Deirdre Fulton, "What Kind of

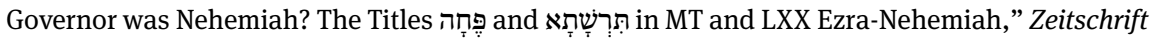
für die alttestamentliche Wissenschaft 130/2 (2018):252-67.

13 Lisbeth S. Fried, The Priest and the Great King: Temple-Palace Relations in the Persian Empire, BJSUCSD 10 (Winona Lake: Eisenbrauns, 2004), 207-8. Fried argues that the Sabbath regulations, specifically the closing of the gates (13:19), were meant to curb high priestly power.

14 Sean Burt, The Courtier and the Governor: Transformations of Genre in the Nehemiah Memoir, JSJSup 17 (Göttingen: Vandenhoeck \& Ruprecht, 2014), 192; see also Marty E. Stevens, Temple, Tithes, and Taxes: The Temple and the Economic Life of Ancient Israel (Peabody, MA: Hendrickson, 2006). While the text of Nehemiah certainly portrays this as the center of economic and religious life in Nehemiah 13, it is not the center of economic or religious life in other parts of the book. Moreover, the possible role of other nearby economic centers, such as Ramat Rahel, draws into question the assumption that the Jerusalem temple functioned as the only economic hub in 
to Nehemiah is a case of eliminating sources of competition controlled by other powerful families, such as the Tobiad family in Amman and Eliashib the priest. ${ }^{15}$ This removal of power, in turn, would also lessen control of the priests in Jerusalem in favor of Nehemiah.

Nehemiah 13:1-3 also presents proper Torah observance as enforced by the people and not the priests. ${ }^{16}$ Namely, Deuteronomy 23:4-7 prohibits the Ammonites and Moabites in the sanctuary - a law one would expect priests to enforce. Yet in Nehemiah 13, this prohibition is carried out by the people. ${ }^{17}$ This prohibition also applies to Nehemiah's removal of Tobiah from the storeroom that Eliashib, the priest, had given to him. Thus, in these two instances the priests are depicted as ineffective leaders, thereby suppressing their powers in favor of Nehemiah or the people. The Levites, however, are not suppressed in comparison to the priests, as evidenced in Nehemiah 13. Specifically, Levites are given a role in the treasury collection, which is a departure from Torah regulations. Yet even these Levitical activities are a consequence of Nehemiah's help. Ezra 1 and Nehemiah 13 provide a framework for the texts and are suggestive of the roles that the priests and Levites played in the Jerusalem community, but not determinative enough so other texts must be explored.

\subsection{Ezra 3}

In contrast to the minor role that the priests and, to a lesser extent, the Levites play in Ezra 1 and Nehemiah 13, Ezra 3 presents the priests and Levites functioning in specific cultic roles. Set within the return of Jeshua the priest and Zerubbabel the governor to Judah, an altar is built and offerings are made (Ezra 3:2), in keeping

Judah. For a discussion of the possible role of Ramat Rahel in Persian period Judah, see Gary N. Knoppers, Judah and Samaria in Postmonarchic Times: Essays on Their Histories and Literatures, Forschungen zum Alten Testament 129 (Tübingen: Mohr Siebeck, 2019), 153-75.

15 Fried, The Priest and the Great King, 210. Fried rightly points out that Nehemiah's biggest enemies are the heads of several families, including Tobiah and Eliashib, as well as Sanballat and Geshem.

16 Eskenazi, In an Age of Prose, 122; Eskenazi views 13:1-3 as the "finale" that depicts a community purified. This "finale" is in relation to the events in Nehemiah 12. Others, such as Wright, Rebuilding Identity, 315-17; Pakkala, Ezra the Scribe, 223-24; Becking, Ezra-Nehemiah, 313-14 view the third person narrative vv. 13 as a later addition to the first-person material in Nehemiah 13. Either way, vv. 1-3 are not originally part of the other material in Nehemiah 13.

17 Becking, Ezra-Nehemiah, 316. Becking is correct in his observation that "the initiative for the action, unlike the four following episodes, lies with the people themselves and not with Nehemiah.” 
with what was "written in the Torah of Moses the man of God" (כתוב בתורת משה (איש־האלהים practice, as well as keeping the festival of Sukkot. Concerning the priests, Nissim Amzallag states, "their initiative in restoring the altar and renewing the sacrifices (Ezra 3:3) presents them as leaders of the community, the initiators of Israel's postexilic rebirth." Certainly, in this instance the priests stand out as such. But these activities are not just the actions of the priests. In Ezra 3:2, Jeshua and fellow priests, as well as Zerubbabel and his kin, are responsible for rebuilding the altar and establishing sacrifice. ${ }^{18}$

Several scholars have questioned which texts in the Torah influenced the description of sacrificial activities in Ezra 3. Ezra 3:3-6 describes the sacrificial activities which took place on the newly-built altar in Jerusalem. The details of the sacrificial practices are clearly in line with Torah regulations, particularly with reference to the description of Sukkoth. Christophe Nihan asserts that the phrase "appointed times of Yahweh," found in Ezra 3:5, indicates the "time set apart in the year by Yahweh himself."19 This phrase, also found in another postexilic text, 2 Chronicles 2:3, is present in Leviticus 23:2 and 38. ${ }^{20}$ Nihan concludes that, while missing from the earlier calendars in Exodus 23 and Deuteronomy 16, Leviticus 23 "reflects a typically priestly conception (see Gen 1:14; Ezek 44:24)." Bob Becking maintains that Ezra 3:3-6 is in harmony with Sukkoth descriptions in Numbers 29:12-38 and Deuteronomy 16:13-15. ${ }^{21}$ Amzallag argues that the description of Sukkoth in Ezra 3 is in keeping with Leviticus 23:33-43, Numbers 29:19-39, and 2 Chronicles 8:13, namely that the festival focuses on sacrifice. Ezra 3:3-6 presents Sukkoth in keeping with priestly conceptions of sacrifice, and highlights the priestly role in such a celebration as well as the other sacrificial activities throughout the year.

The Levites are not explicitly mentioned until the rebuilding efforts are underway in the second year of their return (3:7-10). After their appointment, the Levites function as overseers in the rebuilding of the House of God (בית האלהים).

18 Sara Japhet, "Sheshbazzar and Zerubbabel: Against the Background of the Historical and Religious Tendencies of Ezra-Nehemiah,” ZAW 95 (1982):84; Eskenazi, In an Age of Prose, 51.

19 Christophe Nihan, From Priestly Torah to Pentateuch: A Study in the Composition of the Book of Leviticus, FAT 25 (Tübingen: Mohr Siebeck, 2007), 510.

20 Nihan, From Priestly Torah to Pentateuch. For a discussion of the postexilic nature of this phrase, see Klaus Grünwaldt, Das Heiligkeitsgesetz Leviticus 17-26: Ursprüngliche Gestalt, Tradition und Theologie, BZAW 271 (Berlin: De Gruyter, 1999). Nihan also points out that Lev 23 is noticeably different from other calendars that treat feasts as "climactic events in the agricultural cycle, as in the previous calendars (Ex 23 and Deut 16)."

21 Becking, Ezra-Nehemiah, 56; Amzallag, “The Authorship of Ezra and Nehemiah,” 286. 
The Levitical roles, however, do not extend to any sacrificial practices, which are significant sacerdotal activities of the priests in this context. ${ }^{22}$ Both priests and Levites are together for the festivities connected to laying the foundation of the temple (3:10).

\subsection{Ezra 7 and 8}

The special role of the priests in Ezra 3 is also evident in Ezra 7 with the gathering of the family heads during the period of Ezra's return. ${ }^{23}$ In chapter 7, Ezra is described as a "priest and scribe," descended from Aaron the "head priest” (הכהן הראש of the LORD, and to do it, and to teach the statutes and ordinances to the people" (עזרא הכין לבבו לדרוש את־תורת יהוה ולעשת וללמד בישראל חק ומשפט). While Ezra is gathering people by the Ahava river (Ezra 8), there are priests who are willing to return, but no Levites (8:15b). Ezra then sends for certain Levites, whom he names and describes as "ones with understanding” (מבינים), as well as other temple personnel. ${ }^{25}$ Rather than reading the failure of the Levites to appear upon Ezra's first gathering as a critique on this group, Juha Pakkala argues that 8:15b-20 is an insertion into the text, correcting the lack of reference to the Levites. ${ }^{26}$ Pakkala also states, "the purpose of the expansion in vv. 15b-20 was to emphasize the role of the Levites in Ezra's mission ... the addition is connected to similar additions that emphasize the role of Levites met throughout the Ezra narrative.” These Levitical insertions may have functioned for many different purposes, but at the least they function as a way to make sure the Levites are included in the narrative.

22 Eskenazi, In an Age of Prose; Japhet, “Sheshbazzar and Zerubbabel.” Both Eskenazi and earlier Japhet maintain that Ezra 3:2 should be understood as the entire community coming together to rebuild the altar and establish sacrifice. While this may be the case, it is still noteworthy that the Levites are not mentioned.

23 In compositional models of Ezra, ch 7-10 is considered part of the so-called "Ezra Memoir." See Fried, Ezra; Becking, Ezra-Nehemiah for an overview of different compositional models for Ezra.

24 Pakkala, Ezra the Scribe, 242. Pakkala argues that Ezra 7:6a is the original introduction of Ezra, and the position of priest (7:1-5) is a later addition. The original role of Ezra is beyond the purview of this paper, but I take Pakkala's compositional model, that Ezra is first and foremost a scribe and then later a priest, as a given and $1-5$ as an addition to the earlier vv. 6 and following. 25 Pakkala notes certain text-critical issues between Ezra 7 and 8. Juha Pakkala, "The Disunity of Ezra-Nehemiah,” in Unity and Disunity In Ezra-Nehemiah, eds. Mark J. Boda and Paul L. Redditt, Hebrew Bible Monographs (Sheffield GB: Sheffield Phoenix Press, 2008), 200-215.

26 Pakkala, Ezra the Scribe, 59-60. 
Moreover, this may be evidence for Levitical authorship, or it may be evidence of a writer who understands the need for Levites in temple legislation according to Torah laws.

Although this may be an example of Levitical insertion into the text, nonetheless the text portrays a positive image of the priests. In contrast to Ezra 1, the temple vessels entrusted to Ezra to return to Jerusalem, are entrusted first to the priests and then to the Levites. Ezra "sets apart" (אבדיל) twelve priests, and then entrusts them with bringing back silver, gold, and temple paraphernalia for the house of God. Ezra (8:28) then proclaims to the priests, "You are holy to the LORD" (אתם קדש ליהוה). This holiness is extended over the goods that the priests are to bring to Jerusalem (8:29b-29). The Levites are mentioned in the conclusion to these events (v. 30), but not in reference to holiness. This one reference to the priests as holy (קדש) is exceptional within Ezra-Nehemiah. The word "holy" (קדש) appears 13 times in Ezra-Nehemiah in limited contexts, namely to describe food (Ez 2:63/Neh 7:65), the priests (Ez 8:28), vessels (Ez 8:28), God's "holy place” (Ez 9:8), people (specifically זרֵע הקדש in Ez 9:2), certain days (Neh 8:9-11, 9:14, 10:31, and 13:22), and the city of Jerusalem (Neh 11:1 and 18). ${ }^{27}$ This one instance in which the priests are called "holy" is unusual and all the more remarkable since people are not the common recipients of holiness in Ezra-Nehemiah. ${ }^{28}$ The only other use of holy is to describe the people in Ezra 9:2, namely the "holy seed" (זרֵע who are to separate from those who are not part of this group. To summarize, while the Levitical references in Ezra 8:15b-20 aid in bolstering the role of the Levites in this particular narrative, the priests are still the leaders performing the proper cultic responsibilities and are called holy.

These events in chapters 7 and 8 reflect the most-priestly of behaviors that Ezra undertakes in the book that bears his name. A close reading of Ezra reveals that his main function is more closely associated with those of a scribe, and later editing

27 See Harrington, "Holiness and Purity in Ezra-Nehemiah" for a discussion of the term "holy seed" and relevant references; See also Louis C. Jonker, "Melting Pots and Rejoinders? The Interplay among Literature Formation Processes during the Late Persian and Early Hellenistic Periods," VT 70 (2020): 42-54 for the appearance of קדש in Chronicles which, he argues, is significant for understanding the role of the Levites. On p. 48, Jonker points out that, “... from 2 Chronicles 29 onwards numerous connections are made between the Levites and the status of being consecrated or holy." This change, according to Jonker is because the Chronicler "developed this profile of the Levites, and even the 'whole assembly' as being holy under the influence of the redefinition of holiness in $\mathrm{H}$. "

28 Eskenazi, In an Age of Prose, argues that Ezra is commissioning both priests and Levites, calling both "holy". Specifically, she points to the names Sherabiah and Hashabiah, both names of only Levites in other settings (specifically, 8:18-19). This example of "holiness" may be a case of the entire community as considered holy, but it is still significant that the Levites are not named. 
creates an image of a priest. ${ }^{29}$ He does not perform activities that one expects of a priest, however, as outlined in the Torah, namely activities connected to the temple such as sacrifice and overseeing festival events. ${ }^{30}$ The carrying of holy vessels, which the Torah places into the hands of the priests, is not part of Ezra's duties. As Tamara Cohn Eskenazi summarizes, "Ezra is a scribe at the service of a book; his primary affiliation and primary allegiance are to the Torah." ${ }^{31}$ While it is still debated what the Torah of Moses means in Ezra-Nehemiah, Eskenazi's characterization, that Ezra the priest is "first and foremost a scribe," is fitting. ${ }^{32}$ This scribal designation for Ezra, however, does not negate the fact that in Ezra 7 and 8 , the priests and Levites are performing duties expected of them.

\subsection{Nehemiah 8 and 9}

In Nehemiah, the priests and Levites are part of the wall building efforts in Nehemiah 3, and part of the returnees in Nehemiah 7. In Nehemiah 8, the community is gathered for a reading of the Torah, led by Ezra who is first described as a scribe (8:1) and then as a priest (8:2). The Levites are also present (8:7). On the second day of reading, they read about the festival of Sukkoth. Amzallag observes that the Sukkoth celebration follows the parallel lists of Ezra 2//Nehemiah 7 in both books. He states "One would expect the celebration of Sukkot in Ezra and Nehemiah to be as similar as are the respective census lists (Ezra 2:1-70 and Neh 7:6-72)”, but this is not the case. ${ }^{33}$ Whereas Ezra 3 focuses on sacrifice, the text of Nehemiah never mentions this activity, and as a result, downplays the role of the priests. Additionally, in Nehemiah the people are to construct booths and collect branches, which is inconsistent with the prohibition to work in Leviticus 23:35. ${ }^{34}$ Amzallag hypothesizes that one of the reasons for the change is that priests underwent a "loss of prestige" within this narrative, in contrast to the role of priests in Ezra. ${ }^{35}$ He cites Nehemiah 9:1-5 and Nehemiah 12 as examples of their loss of prestige. Specifically, in the "supplication ceremony" in Nehemiah 9, the Levites conduct the ceremony without the assistance of the priests. The characterization of the

29 Pakkala, Ezra the Scribe.

30 See Hannah K. Harrington, “The Use of Leviticus in Ezra-Nehemiah,” JHS 13 (2013): 1-19 for a discussion of cultic behaviors in Ezra-Nehemiah.

31 Eskenazi, In an Age of Prose, 75.

32 Eskenazi, In an Age of Prose, 75.

33 Amzallag, "The Authorship of Ezra and Nehemiah,” 286.

34 Amzallag, "The Authorship of Ezra and Nehemiah," 286.

35 Amzallag, "The Authorship of Ezra and Nehemiah,” 287. 
Levites in Nehemiah 9 is clearly pro-Levitical. Pakkala explains these differences in Sukkoth by tracing the text of Nehemiah 8:13-18 to an earlier form of Leviticus 23:39-43. ${ }^{36}$ While the Sukkoth differences may be the result of an Urtext of Leviticus 23, the change in Sukkoth practices in Ezra 3 to Nehemiah 8 also change the centrality of the priests and Levites in this ceremony. The perceived loss of priestly control may, however, be viewed as a "democratization" (or, at least moving more power into the hands of the people) of ancient Judean religion. ${ }^{37}$ Rather than the priests as the only actors, the people (with the help of the Levites) are now the central actors of this celebration. This quasi-democratization, however, does not extend to sacrifice that was still in the hands of the priests and may be why there is no reference to such a practice.

Although the priests are not elevated in Nehemiah 8 and 9, Nehemiah 10:3639 does offer a point of departure from these portrayals. Following the pledge of the people (including priests, Levites, and temple personnel) to bring goods to the temple, the priests are to accompany the Levites with the collection of tithes. ${ }^{38}$ These tithes, collected by the Levites and the priests, were brought to the storerooms of the sanctuary for, as v. 39 indicates, the "priests who minister" (הכהנים as well as the gatekeepers and singers. This portrayal of the priests and Levites working together is meant as the ideal situation. Nehemiah 12 provides another moment for the community to gather and work together, set within a festival context.

\subsection{Nehemiah 12}

During the dedication ceremony in MT Nehemiah 12:27-43, the priests are only mentioned in four verses (vv. 30, 35, 41, and 43), whereas the instruments and

36 Pakkala, Ezra the Scribe, 163. Pakkala also asserts that the Sukkoth law in Deut 16:13-15 is not responsible for the creation of Neh 8:13-18. He states, "This is significant as it positively indicates that the author regarded another version of this law more authoritative than the one in Deut. This shift in attitude should not be disregarded, as it may be the oldest clear indication within the Ezra tradition that Deut is not the main Pentateuchal source."

37 Japhet, earlier, observes the power moving away from the figureheads and into the hands of the people. She states, "We might call this process 'democratization', with reservations concerning the terminology which does not fully fit the framework of Israelite life, but does hint at the rise of the power of popular representatives in the social-political structure." Japhet, "Sheshbazzar and Zerubbabel," 87; See also Eskenazi, In an Age of Prose.

38 The pledge taken in Neh 10 is a promise of the community to not marry their sons or daughters to the nations, not to sell anything on the Sabbath, to pay the temple tithe, and that the priests and Levites will collect the tithe and bring it to the temple. 
position of the Levites are much more prominent. Amzallag observes, "by means of a literary artifice, it seems that, in contrast to the book of Ezra, the author of Nehemiah intentionally diminishes the ritual importance of both the priests and sacrifice, elevating instead the musical performance conducted by the singers/ Levites." ${ }^{39}$ He highlights the text of MT Nehemiah 12:41, when the priests follow the procession with trumpets. ${ }^{40}$ As well, Nehemiah 12:43 states, "And they offered great sacrifices that day and rejoiced, for God made them rejoice with great joy" (ויזבחו ביום־ההוא זבחים גדולים וישמחו כי האלהים שמחם שמחה). In this example of sacrificing, there are no specific details, but rather sacrifice is presented as a communal activity. Moreover, the placement of this activity, within the part of the ceremony focused on rejoicing rather than the sacrifice, is striking. ${ }^{41}$ The only specific cultic behavior of the priests is their role in playing musical instruments, a role usually relegated to the Levites. In this context, even the priests seem to take on a role traditionally associated with Levites.

While the Levites do play a more prominent role in the processional activities, Nehemiah 12:31 mentions both priests and Levites as part of the purification ceremony. Both priests and Levites are leaders in the purification of themselves, the people, and the city. This is an essential part of the dedication ceremony, and both cultic leaders are equally responsible in this purification.

\subsection{Nehemiah 13 (again)}

Nissim Amzallag's observation regarding Nehemiah 9 and 12 appears to be in keeping with the attention paid to the Levites. Nehemiah 13, however, offers another point of comparison. The priests are guilty of mismanaging the temple, Sabbath, and marriage alliances, and the Levites have returned to their villages. The Levites return because the "portion of the Levites" (מניות הלוים) was not given to them, so they returned to their fields. Nehemiah gathers them, again, and places them in their stations. Whether one reads this text as sympathetic to the Levites is entirely dependent on one's view of the Levites in Nehemiah. The author of this passage in Nehemiah may be more neutral or even possibly sympathetic toward the Levites, but the power still rests in the hands of Nehemiah (and to

39 Amzallag, "The Authorship of Ezra and Nehemiah,” 288.

40 The B, S, A, and Aram. manuscripts are missing the texts found in Neh 12:37-42. See Deirdre N Fulton, Reconsidering Nehemiah's Judah: The Case of MT and LXX Nehemiah 11-12, FAT 80 (Tübingen: Mohr Siebeck, 2015), 150-51.

41 Amzallag, "The Authorship of Ezra and Nehemiah," 287-88. 
a lesser extent the people). With regard to the Torah regulations, Bob Becking observes, "According to Deut 18:2 the Levites were not allowed to possess their own land.” Alternatively, the changes between Deuteronomy 18:2 compared to Nehemiah 13 may be a result of a change in cultural and/or social expectations. ${ }^{42}$

\section{The Priests and Levites in Ezra-Nehemiah Compared}

These textual loci in Ezra-Nehemiah allow for many places to compare the role of priests and Levites in Ezra-Nehemiah in light of their possible roles in the composition of these texts. While it is true that when one compares the text of Ezra to the text of Nehemiah, the text of Nehemiah appears to diminish the role of the priestly power in favor of community power or Nehemiah's power. The priests offer very little leadership within Ezra as well. The role of priests to perform Torah duties, namely perform sacrifices and keep festivals, is more functional and less prescriptive. By this, I mean that they are functionaries performing the actions on behalf of the people, but they are not connected to the establishment or enforcement of these activities. They are also not prescribing ritual in the way that Moses prescribes instructions in Leviticus, or Ezekiel prescribes instructions in his Temple Vision (for example, the priestly instructions to the people for separating clean from unclean). In the few cases in which the priests are most directly involved, namely Ezra 3, the description of what the priests are supposed to do - in line with their activities in the Torah - are to sacrifice specifically during festival events. Yet these moments are uncommon within the text of Ezra-Nehemiah. Priests are depicted as sacrificing during the time of Zerubbabel and Jeshua, but in the time of Ezra this activity is never mentioned. Priests, at times, help transport temple vessels (Ezra 8), but not all the time (Ezra 1). Similarly, in Ezra 3:8, the Levites supervise the rebuilding efforts and help transport temple vessels from Babylon to Judah (in Ezra 8), but not all the time (Ezra 1).

In Nehemiah, the minor priestly roles are more muted, as one sees by the changes in the Sukkoth activities. Specifically, the people are responsible for Sukkoth. By the end of the book, Nehemiah (or the people) performs certain priestly functions, namely reforming the community. The series of reforms in Nehemiah 13 are almost exclusively in the hands of Nehemiah. Even the collection of tithes, which according to Nehemiah 10:36-39 were to be collected by the

42 Becking, Ezra-Nehemiah, 319. 
Levites and priests, is not fulfilled. Nehemiah steps in to reinstate the Levites but not the priests, which is a noteworthy change in comparison to 10:36-39. Thus, while the Levites may be promoted in Nehemiah compared to their role in Ezra, they, like the priests, are under the jurisdiction of Nehemiah.

\section{Conclusion}

The final editors of Ezra-Nehemiah synthesized a series of narrative vignettes and lists that focus on the promotion of Jerusalem and Judah. Within this community, the priests and Levites are central figures in the rebuilding efforts. Yet their roles as builders are not a rehashing of Priestly or even Holiness legislation in the Torah. Rather, the priests in Ezra-Nehemiah function in limited cultic settings. In the case of the book of Ezra, the priestly functions are constrained in nature, so much so that festivals are not a main focus of the book. In the example of Nehemiah, priestly functions are even more muted.

In light of these limited roles, it is unlikely that these editorial activities should be credited to the priests. It is true that the Levites fare better in Ezra-Nehemiah. Yet when compared to other postexilic literature, namely 2 Chronicles 29-37 which praises the Levites and calls them "holy" on several occasions, Ezra-Nehemiah does not appear to be solely Levitical in nature. ${ }^{43}$ Rather, the performative rather than prescriptive nature of the priests and Levites limits the power that both groups possess. One should consider authorship in the hands of, as Ehud Ben Zvi has argued, certain Judean literati. ${ }^{44}$ And, in such case, the authorship is in the hands of the Judean literati in conversation with the Jerusalem temple community made up of Levites as well as priests..$^{45}$

43 Jonker, "Melting Pots and Rejoinders?"

44 Ehud Ben Zvi, "Introduction: Writings, Speeches, and Prophetic Books-Setting an Agenda," in Writings and Speech in Israelite and Ancient Near Eastern Prophecy, ed. Ehud Ben Zvi and Michael H. Floyd, SBL Symposium Series 10 (Atlanta: SBL, 2000), 1-30; See also Jones, "Embedded Written Documents," 162. Jones does not connect the composition of Ezra and Nehemiah simply to the temple elite, but rather to elite Judeans who were part of the "scribal literati." This "scribal literati" was familiar with textual traditions in Judah and also "exposed to the literary forms of their overlords." This more comprehensive view of authorship helps explain the seemingly different voices and/or divergent textual traditions within Ezra and Nehemiah.

45 My sincerest thanks for the helpful feedback from Tamara Cohn Eskenazi, Chadwick Eggleston, Christopher Jones, and two anonymous reviewers on this article. 